Vol. 6, No. 1, 2020

\author{
Myroslav Yatsiv
}

\title{
STENOGRAPHY OF LIGHT IN THE ARCHITECTURE OF MODERN THEATER BUILDINGS
}

\author{
Associate Professor of the Department of Architectural Environment Design \\ Lviv Polytechnic National University, Lviv \\ e-mail: Myroslav.B.Yatsiv@lpnu.ua \\ orcid: 0000-0003-3721-7791
}

Received: 05.05.2020 / Revised: 07.06.2020 / Accepted: 10.06.2020

(C) Yatsiv M., 2020

https://doi.org/10.23939/as2020.01.046

\begin{abstract}
The article discusses the role and functions of light in the space of modern theater buildings outside the auditorium and stage space. The architectural and structural factors of the formation of the lighting environment in modern theater buildings are determined; trends and features of the functioning of light in the space of modern theaters are revealed. The influence of the architectonics of buildings on the nature of the illumination of theatrical spaces is established. The experience of the formation of the lighting environment of theater buildings on the example of modern domestic and foreign theaters is analyzed.
\end{abstract}

Key words: theater buildings, natural light, theater lighting environment.

\section{Problem statement}

Light is the substrate of the visual image, its essence, and its basis. Light in a performance is a means of immersing the viewer into a theatrical atmosphere, conceived by the director and created by an artist of light and actors. Set design now closely linked to directing. The first hypnotic impulse that actively acts on the viewer is light. Everything the human eye sees is an endless ocean of combinations of light. Therefore, set design can be considered as a dynamic construction of light streams (Zakharov, 2019).

In a theater building, outside the stage space, natural light plays an important role. The architect should not only understand the nature of light but also be able to manipulate it to create the desired architectural image, mood, and appropriate atmosphere in the interior. Creating a luminous environment in the architecture of theater by the means of natural light is a special art of creating an emotional experience by a person of the dynamic space of a theater building and its architectonics. With the help of light, creative, artistic tasks solved, which reduced to revealing volumes and textures of architectural form, light-shade, and color of the object environment. Natural and artificial lighting and visual effects provide not only the visibility of the subject environment but also the necessary character of the theatrical space. Every kind of light in the theater fulfills its aesthetic, artistic, and utilitarian technological task. Thanks to the light, the viewer immediately evaluates the culture and aesthetics of the theatrical spaces.

Light in the space of a theater building plays several roles. Primarily, it is a communicative-directional function, when light acts as a kind of "guide" and focuses the attention of visitors on high light areas and bright objects, directing people in the appropriate direction (Gusev, 1973). The typologically hierarchical aspect of light related to the features of illumination in the context of vision work in premises of various purposes, a combination of conditions of illumination of functional zones and groups of premises in the structure of a theater building. According to the morphological and shaping role in the space of the theater building, such lighting conditions are created that correspond to the correct perception of the architectural form or change that perception in the desired direction, in accordance with the architect's design. A special role in the architecture of 
theaters played by the imaginative-associative-creative level of illumination, when in a person during visual perception of the light image in the imagination there are associations with landscapes of nature or elements of anthropogenic object origin (Kazakov, 2010).

The question of the harmony of architecture and light considered in the unity of the historical and socioeconomic conditions of the development of society. Natural light, while remaining relatively unchanged, in all epochs determined the nature of the perception of architectural objects and environment, emphasized the light and color architecture of buildings, influenced the perception of form, and was, at the same time, a determining factor in the creation of emotions associated with visual perception (Kazakov, 2010).

\section{Analysis of recent investigation and publication}

Significant changes in the architecture, technique, and methods of construction cause architects to desire a revision of aesthetic ideals and views on the organization of the lighting environment in theaters. According to the researchers of the phenomenon of light in modern architecture and set design, along with the replacement of forms and materials, in modern architecture, the understanding of the meaning of light in the interior space and in its architectural image has changed. Researchers draw attention to various aspects of the functioning of light and the space of theater buildings. In contemporary set design, light considered not only as light design but as a means of strong emotional influence on the viewer and actors (Zakharov, 2019). A means for creating a form of space of the theater and its psychological and emotional filling (Proskuryakov, 2012; Klimko, 2014). As a means of artistic expression (Gudkova, 2010). The theoretical foundations and practice of designing the light environment in architecture are laid in the second half of the 20th century (Gusev, 1973), which have been creatively developed today in many works (for example, Kazakov, 2010). In the writings of well-known Polish researchers, the importance of light in the architecture of public buildings noted, using the example of realized objects of culture (Gyurkovich, 2017).

\section{Objective of the article}

The purpose of the study is to find out how the replacement of the architectural paradigm, social changes in society, the development of construction technologies, and ways of lighting have changed the organization of natural lighting and the architectonics of contemporary theater buildings. The author does not investigate the methods of illumination of the auditoriums and scenes of contemporary theaters, whose illumination is formed by means of artificial light and is a separate important topic of research.

\section{Results and discussions}

In residential, industrial, educational, and office premises, the role of light is primarily utilitarian. The light entering these rooms, the intensity and distribution of the interior space determined by practice, ergonomic regulations depending on the purpose of the room, and the needs of creating a comfortable working environment. The utilitarian function of natural light in many cultural institutions, including theatrical buildings, is not important. In them, natural light is sometimes undesirable, the necessary comfort of visual perception achieved by means of artificial lighting.

There was an atmosphere of pomp in historic theater buildings. The viewer, who entered the interior space, felt the atmosphere of "seclusion" of the interior. Thick walls and a small number of windows reliably shield the interior from the environment, from street noise and sunlight, with virtually no visual connection to the urban environment. Visitors' attention focused on interior design and communication with other viewers before the show and during intermission.

According to the type of organization of the lighting environment, modern theater buildings divided into three large groups. The first group includes theatrical buildings with the traditional organization of the lighting environment - natural light penetrates into the interior in small portions through a small number of light 
openings in the structure of the exterior walls. The interior of the room mainly illuminated by artificial light. In the second group of theaters, we observe a more active disclosure of the internal space. Partially the outer walls replaced by transparent stained-glass windows, structural structures made of glass. The third group includes theatrical buildings, the walls, and even the roofs of which are made of translucent or transparent materials.

By By the method of organizing the light environment by the first group of theatrical buildings is the Podil Theater in Kyiv (2016, reconstruction). The lighting design of the theater offers minimal interference with natural light into the interior space (see Fig. 1a). Natural light penetrates only those areas where it is needed for utilitarian purposes, or to open the interior space outside. The general nature of lighting is formed using natural and electric lighting (see Fig. 1b). General lighting is dominated by electric lighting, which creates unusual lighting effects. For example, a dark ceiling and walls and a brightly lit floor create a theatrical character of interior lighting in the lobby of the theater.

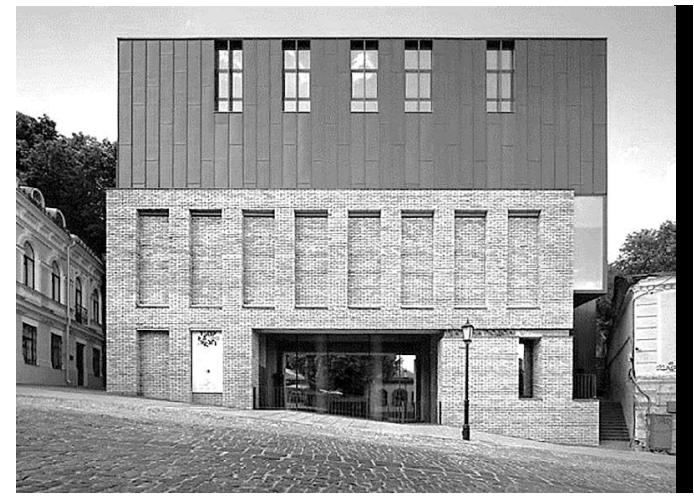

a

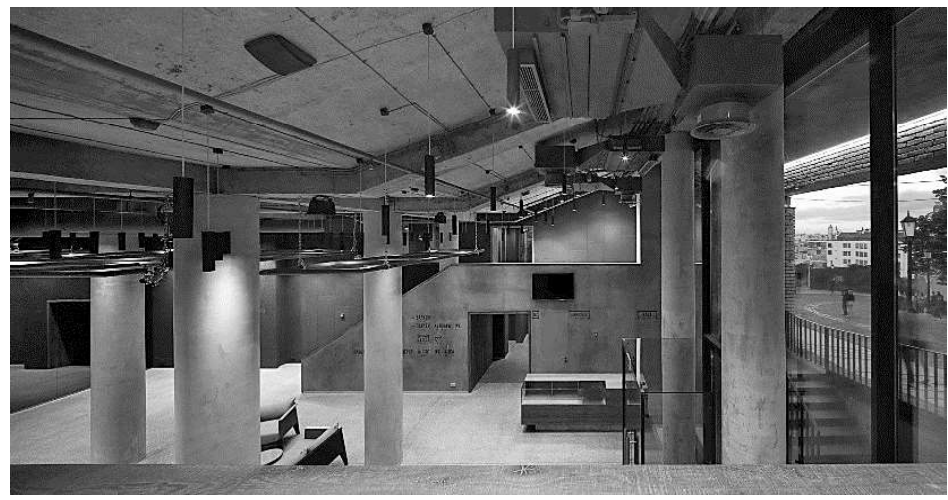

b

Fig. 1. The main facade of the Podil Theater in Kyiv (a); the lobby interior (b) [I]

Not a typical example of contemporary architecture is the Shakespeare Theater in Gdansk (Poland, 2014). Outside, the theatrical ensemble resembles a Sumerian ziggurat, with massive, almost light-tight walls. Natural light, however, makes its way into the space of the theater hall from above, through an open-top roof, allowing viewers to watch the performance in daylight in the open air.

The Walt Disney Concert Hall (Los Angeles, 2003) consists of separate blocks whose facades are made of curved metal sheets. At first glance, the facades of the building completely shield the interior space from sunlight. However, this is not the case. Daylight penetrates the interior space through the exterior glass areas that frame nearly the entire perimeter of the ground floor building, same time, through vertical windows hidden in the configuration of curvilinear wall panels. According to the architect (Frank Gehry), the erratic bends of the steel facade surfaces designed to capture sunlight. Through high windows and glazed areas, daylight enters not only the lobby but also the auditorium.

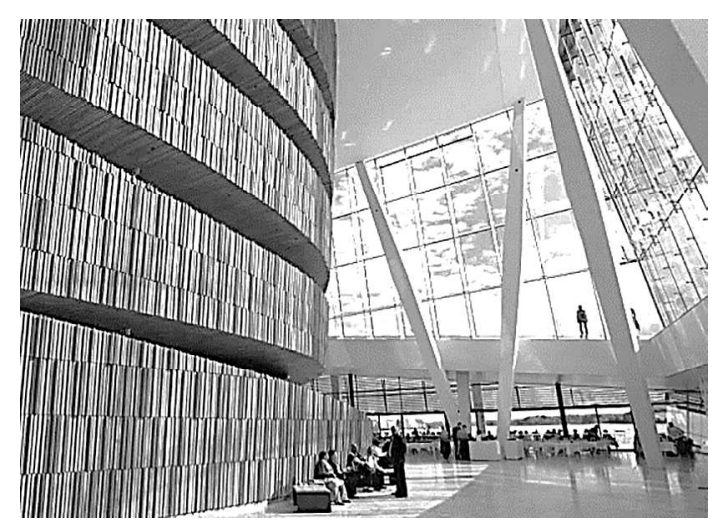

a

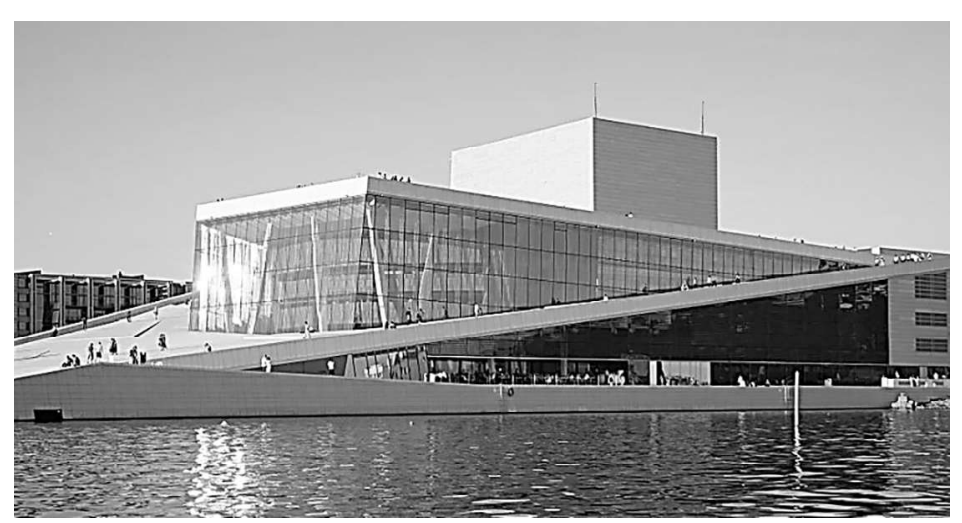

b

Fig. 2. Oslo Opera House interior (a); general view of the theater from the sea (b) [II] 
Among the many modern theaters, the most common is a group of architectural buildings whose walls replaced by glass constructions. This is characteristic of modern architecture as a whole - blurring the boundaries between internal and external, real, and virtual space.

The Oslo Opera House (2008) is unlike the traditional one. Simple planar geometric shapes, monumental volume "glued together" of concrete, steel, and glass, dominate the structure of the building. Glass walls enclose the lobby of the building. Transparent glass panels, joined by a thin metal frame, make the wall as transparent as possible (see Fig. 2a). Natural light penetrating through a glass wall creates luminous effects on the surfaces of the inner walls, the nature of which is constantly changing depending on the intensity, spectrum, and direction of the light fluxes. In the evening, the building "works like a lamp", illuminating the surfaces of the environment (see Fig. 2b).

The shining "cover" of a partially glazed, harmoniously inscribed in the landscape with streamlined forms, Makes the building of a theater in Guangzhou (China 2010) look like precious stones that overflow with silver, or river boulders with moist sides (see Fig. 3a). The author of the project, architect Z. Hadid claimed that during the design of the opera house in Guangzhou, she drew inspiration from the natural landscape - rivers, gorges, boulders, and mountain slopes. The Opera building designed as a stylization of two stones on the riverbank. Impressions and unusual facades enhanced, where concrete structures are interspersed with fabricated glass and metal structures. These transparent inserts allow natural light to penetrate deeply into the interior of the building. Natural light creates unusual dynamic light effects on curved wall surfaces in some rooms and provides ergonomic uniform illumination in others.

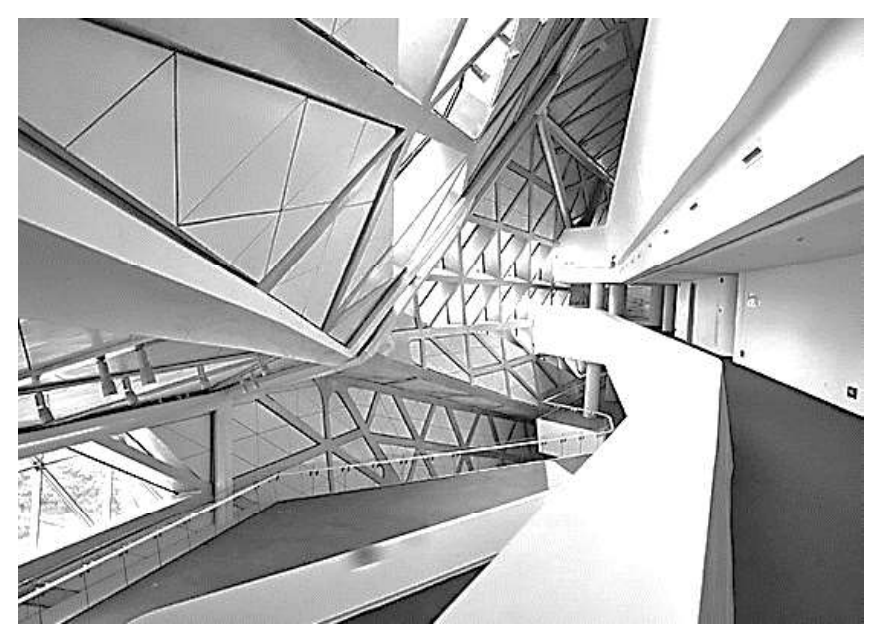

a

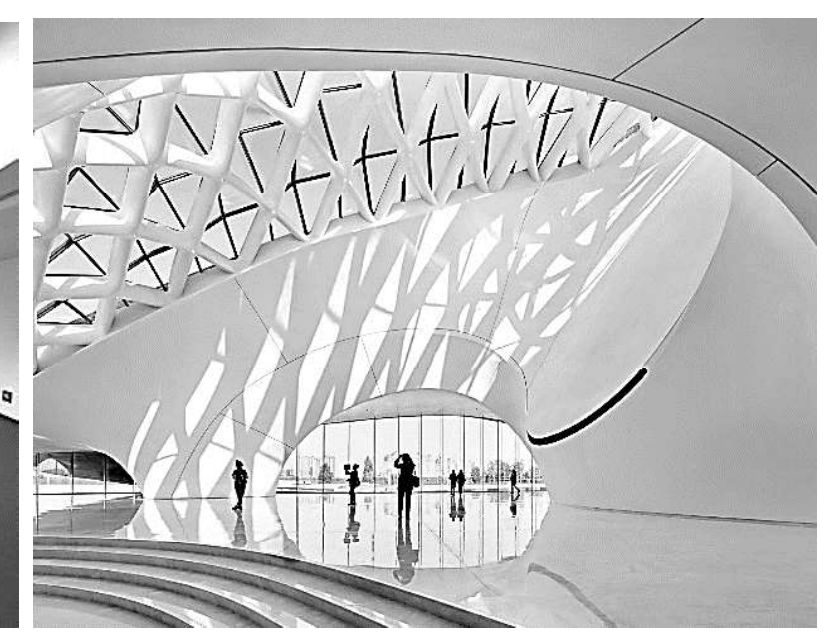

b

Fig. 3. Natural light in the Guangzhou Opera House (a); the light in the lobby of the Harbin Opera House (b) [III]

The architecture of the Harbin Opera House (China, 2015), in streamlined forms, is reminiscent of the architectonics of a theater in Guangzhou. Smooth aluminum wall panels and glass pyramidal roof structures have become the material by which the desired visual effect has been achieved the combination of architectural forms with the landscape. Entering the house, visitors enter the lobby - a large light atrium. The atriums of the large and small halls maximally saturated with natural light. Sunlight enters through large panoramic windows on the sidewalls and glass roof, creating an interesting game of light shading on the ceiling and white curvilinear surfaces of the lobby walls (see Fig. 3b). The large arched windows in the sidewalls, which start from the floor, not only get light but also give a great visual connection to the environment. The transparent roof partially covers the large auditorium. Thanks to the glass roof, sunlight enters the large hall during the day and the darkness of the starry sky envelops the audience in the evening. In the middle of another, smaller hall, the interior visually connected to the 
environment thanks to a large panoramic window behind the stage. Not only does this window provide a natural backdrop for musical orchestras as a continuation of the environment, but it also creates a dynamic set design due to the changing nature and intensity of daylight. The Harbin Opera House is an example of a successful combination of the interior space of the building with the outside environment. Natural light is the determining factor in this relationship.

There are also modern theatrical buildings in which natural light penetrates from all directions, thanks to the use of frame structures and glass panels (see Fig. 4b). The Harpa Concert Hall and Convention Center in Reykjavik implemented the basis of the principle of complete transparency (Iceland, 2011). The lobby of the hall, the exterior walls, and the coverings are made of transparent glass panels of light blue and light yellow colors, which mounted in a steel frame. In them, the natural light is differently reflected and scattered, creating the illusion of dynamic space, the nature of which changes throughout the day. The brightness of the glass surfaces contrasted with the dark gray concrete, from which the walls of the theater hall, stairs, balconies, and more made. Visitor vision, which reflexively searches for brighter surfaces in space, directed, first, to the transparent wall and the urban landscape behind it (see Fig. 4a). The lobby of the building plays the role of a kind of urban "living room" because the natural light that penetrates the interior creates a visible sense of free space and direct communication with the environment. In the lobby and on the sidelines, filled with natural light, visitors can not only have fun before the concert, get distracted from everyday life, sit in cafes or visit small shops, but also enjoy the magnificent views of the sea. At night, the "Harpa" illuminated by a huge number of LED light sources embedded in a steel frame of glass "bricks". The building with its light, like a huge art-framed diamond, floods the expanse of the sea and harbor with multi-colored glow.

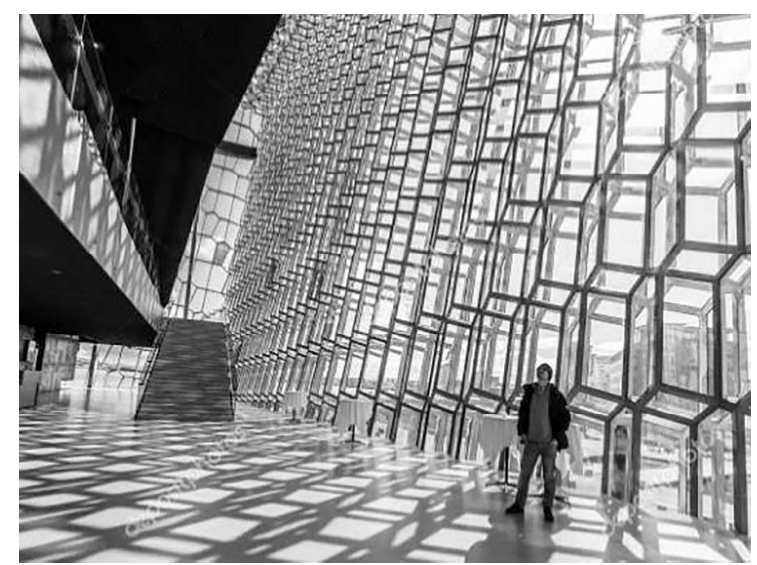

a

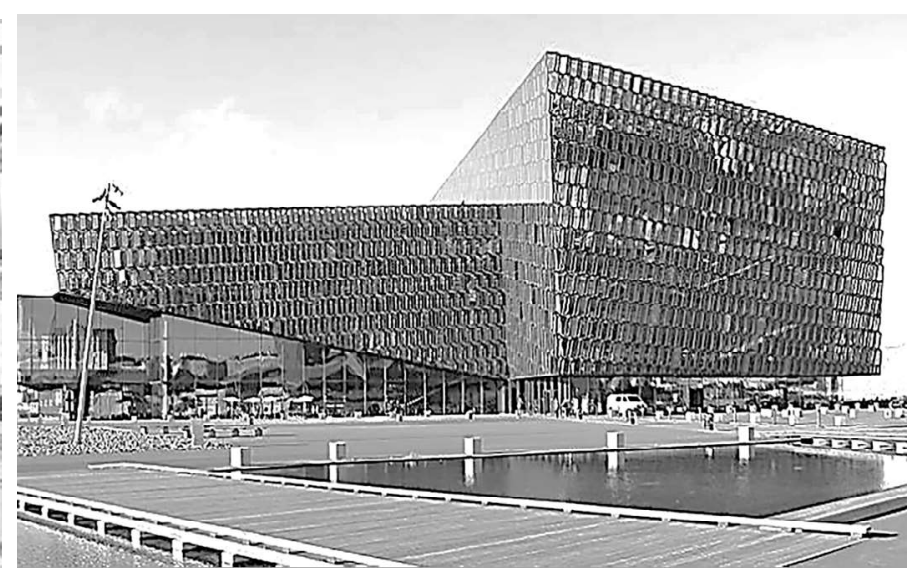

b

Fig. 4. The natural light of the lobby of the Harpa Concert Center in Reykjavik (a); image of the Concert Center (b) [IV]

\section{Conclusions}

The achievements of modern architecture have significantly expanded the means of natural light in shaping the space and architectonics of theater buildings. This evidenced by the practice of the construction of many contemporary theaters. Architecture offers new planning solutions, new spatial forms, and designs following trends in architecture and design, allowing natural light to penetrate all the most remote places of theatrical space. Today, light not only performs utilitarian functions of illumination but also reveals the character of architectural form, gives emotional depth to architectural space, is a means of creating a figurative, associative, and creative perception. Thanks to the use of extensive glazing and various artificial lighting, contemporary theater architecture reflects a new reality - the blurring of the boundaries between internal and external, real and virtual space. Due to the use of transparent structures in the facade structure, the natural light 
more actively penetrates the inner space of the theater building, creating a new reality - the openness and accessibility of the theatrical space.

\section{References}

Mateusz Gyurkovich. 2017. Rola światła w architekturze na przykładzie ikonicznych obiektów kultury. Wybrane przykłady. Środowisko Mieszkaniowe. \#18. Wydawnictwo Politechniki Krokowskie, "Światło w architekturze”. pp. 95-106.

Gudkova N. V. 2010. Sczenicheskij svet kak sredstvo khudozhestvennoj vy razitel ’nosti spektaklya: osnovny`e tape stanovleniya. [online] Available at: <https://cyberleninka.ru /article/n /stsenicheskiy-svet-kak-sredstvo-hudozhestvennoyvyrazitelnosti-spektaklya-osnovnye-etapy-stanovleniya $\geq$ [Date of reference 20 January 2020].

Gusev N. M., Makarevich V. G. 1973. Svetovaya arkhitektura. Moskva: Strojizdat.

Zaeva-Burdonskaya E. A., Nazarov Yu. V. 2019. Sczena v svete sofitov. Paradoksy` professii: khudozhnik, svet, teatr. Svetlotekhnika. \# 5. pp. 76-83.

Mark Zakharov. 2019. Svet - e`to mirovozzrenie. O sczenografii i Olege Shejnczise. Available at: <http:// www.Iteatr.ru/directors/oleg-sheyntsis/47/> [Date of reference 20 January 2020].

Kazakov H. V. 2010. Suchasna svitlova arkhitektura. Lviv: Vydavnytstvo "Rastr - 7".

Klymko Z. V. 2014. Vysvitlennia aktualnosti doslidzhennia fenomenu stsenohrafii, yak skladovoi teatralnoi arkhitektury (na prykladi arkhitekturno-stsenohrafichnoi tvorchosti S. M. Lysyka). Suchasni problemy arkhitektury ta mistobuduvannia. \# 36. Kyiv, pp. 63-72.

Mel'nik A. V. 2018. Teatral'no-konczertnoe postanovochnoe osveshhenie. Available at: <https://lightsoundnews.ru/ amelnik-teatralnokontsertnoe-postanovochnoe-osveshhenieosnovy-postanovochnogo-video/ $\geq$ [Date of reference 01 February 2020 ].

Proskuriakov V. I. 2004. Arkhitektura Ukrainskoho teatru. Prostir i diia. Lviv: Vyd-vo Nats. un-tu "Lvivska politekhnika", Vyd-vo "Sribne slovo".

Proskuriakov V. Yarema D. 2012. Stsenohrafiia yak skladova monumentalno-dekoratyvnoho mystetstva interieru teatru. Visnyk Nats. un-tu "Lvivska politekhnika”: “Arkhitektura”. Lviv,. \# 728. pp. 104-108.

\section{Souses of illustration:}

[I] a-https://vesti.ua/kiev/214722-arkhitektor-proekt-teatra-na-podole-utverzhdala-roshen; accessed on 25.02.2020

b - https://nv.ua/ukr/style/kultura/proekt-teatru-na-podoli-peremih-na-konkursi-arkhitekturi-ta-urbanistiki-2474189.html; accessed on 25.02 .2020

[II] a-https://kuku.travel/country/norvegiya/goroda-i-kurorty-norvegiya/oslo/nacionalnyj-opernyj-teatr-norvegii-v-oslo/; accessed on 25.02.2020

b - https://upload.wikimedia.org/wikipedia/commons/3/32/OsloOpera_20080605-1.jpg; accessed on 30.02.2020

[III] a - http://www.etoday.ru/2011/01/opernij-teatr-guanchzhou-ot-za.php; accessed on 30.02.2020

b - http://www.archiblog.com.ua/architecture-design/harbin-opera-house-mad-architects-2/; accessed on 30.02.2020

[IV] a-https://www.123rf.com/photo_102537639_reykjavik-may-02-2018-inside-the-harpa-opera-house-in-reykjavik-

iceland.html; accessed on 30.02.2020

b - https://en.wikipedia.org/wiki/File:Harpa.JPG Author Ivan Sabljak; accessed on 30.02.2020

\section{Мирослав Яців}

Доцент кафедри дизайну архітектурного середовища.

Національний університет “Львівська політехніка", Львів

e-mail: Myroslav.B.Yatsiv@lpnu.ua

orcid: 0000-0003-3721-7791

\section{СТЕНОГРАФІЯ СВІТЛА В АРХІТЕКТУРІ СУЧАСНИХ ТЕАТРАЛЬНИХ БУДІВЕЛЬ}

Анотація. Світло - це субстрат візуального образу, його сутність і основа. В театральному спектаклі світло це спосіб занурити глядача в атмосферу, задуману режисером і створену художником світла та акторами. Усе, ше бачить людське око, являє собою нескінченний океан комбінаиій світла. Тому декорацію вистави можна розглядати як динамічну побудову світлових потоків.

У театральній будівлі, за межами сценічного простору, важливе значення має природне світло. Архітектору треба не тільки розуміти природу світла, але й вміти маніпулювати ним задля створення потрібного архітектурного образу та відповідної атмосфери в інтер'єрі. Створення світлового середовщща в архітектурі театру засобами природного світла - че особливе мистецтво творення емоційного переживання людиною динамічного простору 
театральної будівлі та ї̈ архітектоніки. За допомогою світла вирішуються творчі художні завдання, які зводяться до виявлення обсягів і фактур архітектурної форми, світлотіні та колориту предметного середовища.

За способом організаиї світлового середовища, сучасні театральні будівлі можна поділити на три великі групи. До периої залучимо театри, в яких природне світло потрапляс у внутрішній простір малими пориіями, крізь малочисельні світлові прорізи в структурі зовнішніх стін. У другій групі театрів спостерігасмо активніше розкриття внутрішнього простору. Стіни замінюються напівпрозорим огородженням: вітражами, структурними скляними конструкціями. До третьої групи належать театральні будівлі стіни, навіть покрівля яких виконується з напівпрозорих чи прозорих матеріалів.

За встановленою класифікауією досліджувалось світлове середовище таких театрів: театр Подолі в Києві (Україна), театр Шекспіра в Гданську (Польща), оперний театр в Осло (Норвегія), театри в Гуанчжоу і Харбіні (Китай) та Кониертний центр в Рейк'явіку (Ісландія).

Встановлено, шуо сьогодні світло в театральних будівлях не лише виявляє архітектурну форму, але надає емочійну глибину архітектурному простору, є засобом створення різноманітних асоиіативних образів. Завдяки активному використанню скління сучасна театральна архітектура відображає нову реальність - розмивання меж між внутрішнім та зовнішнім, реальним та віртуальним просторами.

Ключові слова: театральні будівлі, світлове середовище, театральний простір, природне світло 